\title{
Peningkatkan Aktivitas Siswa Menggunakan Media Papan Catur tentang Materi Pewarisan Sifat Kelas IX SMPN 4 Kota Solok
}

\author{
Hurriyati \\ ${ }^{1)}$ Guru SMPN 4 Kota Solok \\ hurriyatisolok@gmail.com
}

\begin{abstract}
Material inheritance is one of the materials in science subjects that students are less interested in. This can be seen from the low motivation of students in learning. In addition, in this material students are required to use a variety of terms that are new to them, using letter symbols to indicate characteristic or genes in order to be able to cross and be able to determine the choice of genotypes and phenotypes resulting from these crosses. The purpose of this study was to increase the activities of students who use chess boards on material inheritance. This research is a Classroom Action Research (CAR) which was conducted in two cycles. The subjects of this study were 30 students in class IXa. The results of this study indicate the use of chessboard media on class nature inheritance material in class IXa students at SMPN 4 Solok City can increase student activity. Thus this media can be used in learning to increase student activity on material inheritance.
\end{abstract}

Keywords : Student activity, Chess board media, Material inheritance

This is an open access article distributed under the Creative Commons 4.0 Attribution License, which permits unrestricted use, distribution, and eproduction in any medium, provided the original work is properly cited. $@ 2020$ by author and Universitas Negeri Padang.

\section{PENDAHULUAN}

IPA adalah salah satu mata pelajaran yang penting sebagai modal kehidupan bagi siswa. Menurut Ariany (2018) guru sebagai pelaksana proses pembelajaran terutama dalam pembelaja ran IPA hendaknya dapat mewujud kan pembelajaran sesuai harapan tersebut. Akan tetapi, pada proses pembelajaran tentang materi pewarisan sifat untuk siswa kelas IX SMP, aktivitas belajar siswa cenderung rendah.

Materi pewarisan sifat memiliki karakter istik tersendiri yang membuat siswa mengalami sedikit kesulitan dalam memahaminya konsep nya, diatarannya adalah :

a. Banyak istilah baru yang digunakan atau terminology pada konsep ini seperti : parental, filial, gamet, alel, homozigot, heterozigot, carier, genotip, fenotip dan lainnya

b. Melakukan persilangan untuk memprediksi kemungkinan sifat yang diturunkan

c. Menggunakan simbol huruf untuk menunjukkan karakteristik suatu gen yang diturunkan

d. Menggunakan papan catur untuk membantu dalam melakukan persilangan

e. Menentukan genotip dan fenotip hasil persilangan
Salah satu upaya yang dapat dilakukan untuk mewujudkan pembelajaran yang konkret dan dapat meningkatkan aktivitas siswa yaitu dengan menggunakan media pembelajaran berupa media papan catur. Media papan catur yang biasa digunakan pada pembelajaran IPA adalah dalam bentuk gambar yang ditulis di papan tulis. Selain itu penerapan media papan catur sudah banyak diterapkan dalam proses pembelajaran, terutama dalam pembelajaran matematika. Hasil penelitian Lestari, dkk. (2018) bantuan media papan catur dapat meningkatkan hasil belajar matematika siswa kelas IV SD. Selain itu, hasil penelitian Ghozi (2017) penerapan media papan catur dapat meningkatkan pemahaman konsep matematika siswa kelas III SD.

Oleh karena itu, perlu diterapkan media papan catur yang tidak hanya digambarkan di papan tulis tentang konsep pewarisan sifat, tetapi juga diharapkan dapat menarik minat belajar siswa. Media papan catur konsep pewarisan sifat, telah dipersiapkan semua kemungkinan gamet, genotip dan fenotip dalam persilangan, shingga saat proses pembelajaran siswa dapat memilih gamet yang dibutuhkan dan langsung memasang nya pada papan catur.

Penerapan media papan catur dalam pembelajaran konsep pewarisan sifat diharapkan 
dapat meningkatkan aktivitas belajar siswa yang positif diantaranya siswa terlibat aktif dalam pembelajaran dengan berusaha untuk memecah kan setiap soal yang diberikan secara cepat dan berebut untuk menyelesaikan soal tersebut di depan kelas. Selain diharapkan dapat meningkat kan aktivitas belajar siswa penerapan media ini juga diharapkan dapat meningkatkan penguasa an siswa terhadap materi pelajaran dan pada akhirnya dapat meningkatkan hasil belajar siswa

Hipotesis penelitian ini adalah melalui penggunaan media papan catur pada materi pewarisan sifat bagi siswa kelas IX $_{a}$ pada semester I Tahun Ajaran 2018/2019 di SMPN 4 Kota Solok dapat meningkatkan aktifitas dan hasil belajar siswa.

Berdasarkan latar belakang masalah di atas, diajukan rumusan masalah sebagai berikut : Apakah melalui penggunaan media papan catur tentang materi pewarisan sifat dapat meningkatkan aktivitas dan hasil belajar IPA siswa kelas IX $_{\mathrm{a}}$ pada semester I tahun ajaran 2018/2019 di SMPN 4 Kota Solok?

Penelitian ini bertujuan untuk meningkat kan aktifitas dan hasil belajar IPA khususnya materi genetika siswa SMPN 4 Kota Solok

\section{METODE PENELITIAN}

Penelitian ini adalah Penelitian Tindakan Kelas (PTK) dilakukan sebanyak dua siklus, mulai dari siklus satu sampai siklus dua. Kemudian analisis data, pembahasan /diskusi hasil dalam kesempatan seminar hasil dan terakhir penyusunan laporan dalam jangka waktu lebih kurang 4 bulan.

Penelitian Tindakan Kelas (PTK) ini bertujuan untuk mengkaji kondisi pembelajaran, merenungkan permasalahan yang terjadi dan mencoba mencari alternatif untuk menyelesaikan masalah tersebut. Untuk itu dilakukan beberapa langkah penelitian, yaitu;

\section{Perencanaan}

Sebelum penelitian dilaksanakan, terlebih dahulu dipersiapkan rencana tindakan antara lain:

a. Menyiapkan prosedur penelitian

b. Menyiapkan perangkat yang mengacu pada langkah yang sudah ditentukan (Rencana Pelaksanaan Pengajaran /RPP)

c. Menyiapkan alat dan bahan pembuatan media, yaitu berupa:

1. Busa tebal yang digunakan sebagai tempat untuk menempelkan papan catur
2. Busa tipis warna hitam untuk membuat kerangka papan catur

3. Busa tipis aneka warna dibentuk persegi ukuran 13x11 cm yang digunakan untuk menuliskan gamet, genotip dan fenotip dan yang lainnya

4. Kain flanel

5. Paku mading

d. Membuat media pembelajaran menggunakan alat dan bahan yang tersebut diatas, yaitu berupa

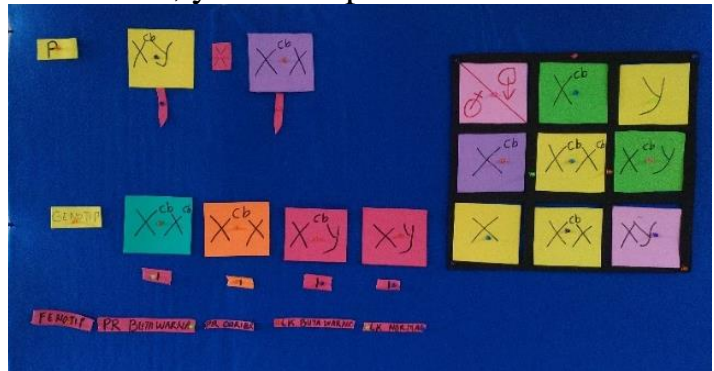

Gambar 1. Contoh model papan catur

e. Membuat kisi-kisi soal

f. Membuat soal tes

g. Menyampaikan rencana penelitian di kelas action

\section{Observasi}

Kegiatan ini dilakukan bersamaan dengan pelaksanaan tindakan. Data yang dikumpulkan pada tahap ini berisi tentang pelaksanaan tindakan dan rencana yang sudah dibuat, serta dampaknya terhadap proses dan hasil pembelajaran yang dikumpulkan dengan alat bantu instrument pengamatan yang dikembanga kan oleh peneliti

\section{Refleksi}

Tahapan ini merupakan tahapan untuk memproses data yang didapat pada saat dilakukan pengamatan (observasi). Data yang didapat kemudian ditafsirkan, dianalisis dan disintesis. Dalam proses ini semua pengalaman, pengetahuan dan teori-teori pembelajaran yang dikuasai dan relevan menjadi bahan pertimbang an dan perbandingan sehingga dapat ditarik suatu kesimpulan yang mantap dan sahih

Pengumpulan data dilakukan di kelas $\mathrm{IX}_{\mathrm{a}}$ SMPN 4 Kota Solok Kecamatan Lubuk Sikarah kota Solok Provinsi Sumatera Barat. Subjek penelitian ini adalah di kelas IX $\mathrm{X}_{\mathrm{a}}$ semester I tahun ajaran 2018/2019. Jumlah siswa di kelas IXa adalah 30 orang dengan rincian 11 orang perempuan dan 19 orang laki-laki. Kelas ini dipilih menjadi subjek penelitian karna siswa di kelas tersebut memiliki karakteristik jumlah siswa laki-laki yang lebih dominan daripada 
perempuan, hal ini menyebabkan suasana dalam kelas didominasi laki-laki yang terkadang memiliki tingkat keseriusan belajar yang kurang, aktifitas negatif yang menonjol seperti berbicara dan bergerak. Mereka lebih menyukai sesuatu yang nyata dihadapan mereka

Sumber data dalam penelitian ini adalah data kualitatif dan data kuantitatif. Data kualitatif adalah adalah data hasil observasi guru tentang proses pembelajaran. Sedangkan data kuantitatif adalah data hasil belajar siswa setiap akhir siklus yang diperoleh dengan mengguna kan lembar evaluasi.

Dalam penelitian ini teknik pengumpulan data yang dilakukan adalah observasi terhadap proses pembelajaran untuk mendapatkan data aktifitas siswa dan dengan teknik tes. Tes yang digunakan dalam hal ini adalah tes tertulis untuk mendapatkan hasil belajar siswa

Alat pengumpulan data yang digunakan dalam penelitian ini yaitu lembaran observasi aktifitas siswa dalam pembelajaran dan soal tes atau dengan butir soal tes untuk hasil belajar siswa. Validasi data dalam penelitian ini perlu dilakukan untuk memperoleh data yang akurat. Untuk data kuantitatif, yang perlu di validasi adalah instrumennya yaitu dengan membuat kisikisi agar terpenuhinya validitas konstruk dan teoritik.

Analisis data dilakukan setelah penelitian selesai dilakukan, dalam penelitian ini data yang diperoleh adalah data kualitatif dan kuantitatif yaitu data aktifitas siswa dan hasil belajar siswa yang dianalisis dengan analisis deskriptif komparatif. Analisis deskriptif komparatif untuk data aktifitas siswa merupakan proses membandingkan aktifitas siswa pada kondisi awal, saat siklus 1 dan saat siklus 2. Analisis deskriptif komparatif untuk yaitu dengan membandingkan nilai tes kondisi awal, nilai tes setelah siklus 1 , nilai tes setelah siklus 2 kemudian di refleksi

\section{HASIL DAN PEMBAHASAN}

\section{Keadaan Sebelum Penelitian}

\section{Deskripsi Keadaan Aktifitas Guru Sebelum Penelitian}

Tabel 1. Deskripsi Keadaan Aktifitas Guru Sebelum Penelitian

\begin{tabular}{|c|c|c|c|c|}
\hline \multirow[b]{2}{*}{ No } & \multirow{2}{*}{$\begin{array}{c}\text { Aktifitas } \\
\text { Mengajar Guru }\end{array}$} & \multicolumn{2}{|c|}{ Kondisi } & \multirow[b]{2}{*}{ Ket } \\
\hline & & Muncul & $\begin{array}{c}\text { Tdk } \\
\text { muncul }\end{array}$ & \\
\hline & $\begin{array}{l}\text { PENDAHULUA } \\
\mathrm{N}\end{array}$ & & & \\
\hline
\end{tabular}

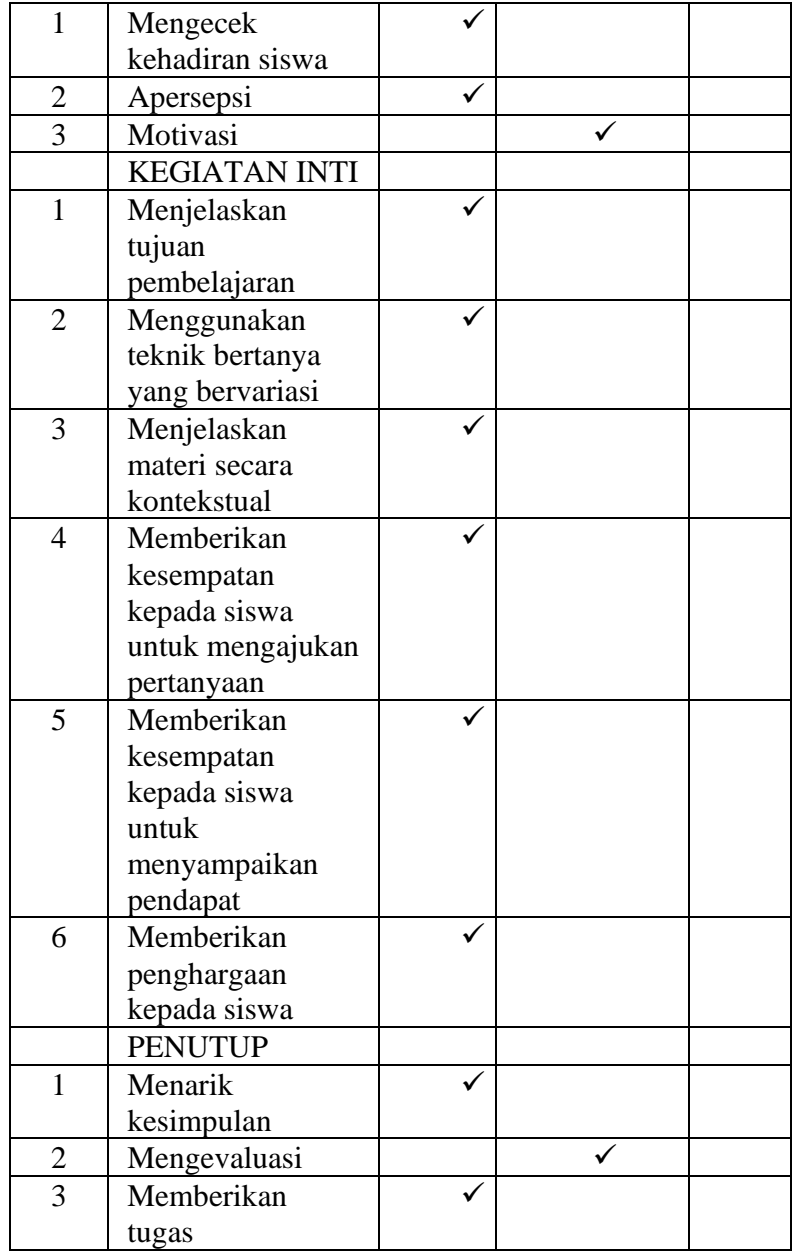

2. Deskripsi Keadaan Aktifitas Siswa Sebelum Penelitian

Tabel 2. Deskripsi Keadaan Aktifitas Siswa Sebelum Penelitian

\begin{tabular}{|c|c|c|c|}
\hline $\mathrm{NO}$ & $\begin{array}{c}\text { Aktifitas Siswa } \\
\text { yang Diamati }\end{array}$ & Jumlah & $\begin{array}{c}\text { Persentase } \\
(\%)\end{array}$ \\
\hline 1 & $\begin{array}{l}\text { Menunjukkan } \\
\text { kesiapan belajar }\end{array}$ & 14 & 47 \\
\hline 2 & $\begin{array}{l}\text { Mendengarkan } \\
\text { penjelasan guru }\end{array}$ & 20 & 67 \\
\hline 3 & $\begin{array}{l}\text { Mencatat } \\
\text { pelajaran/tugas }\end{array}$ & 25 & 83 \\
\hline 4 & $\begin{array}{l}\text { Mengerjakan } \\
\text { tugas }\end{array}$ & 18 & 18 \\
\hline 5 & $\begin{array}{l}\text { Berdiskusi dalam } \\
\text { menyelesaikan } \\
\text { tugas }\end{array}$ & 11 & 37 \\
\hline 6 & $\begin{array}{l}\text { Tampil } \\
\text { menyelesaikan } \\
\text { tugas }\end{array}$ & 10 & 11 \\
\hline
\end{tabular}


3. Deskripsi Keadaan Hasil Belajar Siswa Sebelum Penelitian

Tabel 4. Deskripsi Keadaan Hasil Belajar Siswa Sebelum Penelitian

\begin{tabular}{|c|c|c|c|}
\hline No & $\begin{array}{c}\text { Interval } \\
\text { nilai }\end{array}$ & Jumlah & $\begin{array}{c}\text { Persentase } \\
(\%)\end{array}$ \\
\hline 1 & $<50$ & 8 & 27 \\
\hline 2 & $51-60$ & 7 & 23 \\
\hline 3 & $61-70$ & 6 & 20 \\
\hline 4 & $71-80$ & 4 & 13 \\
\hline 5 & $81-90$ & 4 & 13 \\
\hline 6 & $91-100$ & 1 & 1 \\
\hline Jumlah & 30 & 100 \\
\hline Nilai Rata-rata & \multicolumn{3}{|c|}{64} \\
\hline Nilai Terendah & \multicolumn{3}{|c|}{98} \\
\hline Nilai Tertinggi &
\end{tabular}

\section{Refleksi Awal Untuk Penelitian Siklus 1}

Hasil observasi dari tabel 3.data aktifitas siswa pada kondisi awal adalah siswa menunjukkan kesiapan belajar sebesar $47 \%$, siswa yang mendengarkan penjelasan guru sebesar $67 \%$, siswa yang mencatat pelajaran/tugas sebesar $83 \%$ dan siswa yang mengerjakan tugas mencapai $60 \%$ sedangkan siswa yang berdiskusi dalam menyelesaikan tugas $37 \%$ serta siswa yang tampil menyelesaikan tugas sudah mencapai 33\%

Hasil evaluasi pada kondisi awal, penguasaan siswa terhadap materi pembelajaran yaitu dengan rata-rata 64, dengan penyebaran nilai yang merata serta rentang nilai yang terlalu jauh yaitu nilai terendah 40 sedangkan capaian nilai tertinggi pada yaitu 98

Kondisi ini belum memuaskan penulis, makanya berusaha untuk mengadakan perbaikan pada pembelajaran genetika dengan menghadirkan secara langsung dihadapan siswa bentuk dari papan catur itu serta memberikan kesempatan pada mereka untuk terlibat langsung menggunakannya saat melakukan persilangan untuk memperoleh kemungkinan genotip dan fenotip keturunan.
B. Hasil Penelitian Siklus Pertama

1. Deskripsi Keadaan Aktifitas Guru Pada Siklus 1

Tabel 5. Deskripsi Keadaan Aktifitas Guru Pada Siklus 1

\begin{tabular}{|c|c|c|c|c|}
\hline \multirow[b]{2}{*}{$\begin{array}{l}\mathrm{N} \\
\mathrm{o}\end{array}$} & \multirow[b]{2}{*}{$\begin{array}{c}\text { Aktifitas } \\
\text { Mengajar Guru }\end{array}$} & \multicolumn{2}{|c|}{ Kondisi } & $\mathrm{Ke}$ \\
\hline & & $\begin{array}{c}\text { Muncu } \\
1\end{array}$ & $\begin{array}{c}\text { Tdk } \\
\text { muncu } \\
1\end{array}$ & \\
\hline & $\begin{array}{l}\text { PENDAHULUA } \\
\mathrm{N}\end{array}$ & & & \\
\hline 1 & $\begin{array}{l}\text { Mengecek } \\
\text { kehadiran siswa }\end{array}$ & $\checkmark$ & & \\
\hline 2 & Apersepsi & $\checkmark$ & & \\
\hline 3 & Motivasi & $\checkmark$ & & \\
\hline & KEGIATAN INTI & & & \\
\hline 1 & $\begin{array}{l}\text { Menjelaskan } \\
\text { tujuan } \\
\text { pembelajaran }\end{array}$ & $\checkmark$ & & \\
\hline 2 & $\begin{array}{l}\text { Menggunakan } \\
\text { teknik bertanya } \\
\text { yang bervariasi }\end{array}$ & $\checkmark$ & & \\
\hline 3 & $\begin{array}{l}\text { Menjelaskan } \\
\text { materi secara } \\
\text { kontekstual } \\
\end{array}$ & $\checkmark$ & & \\
\hline 4 & $\begin{array}{l}\text { Memberikan } \\
\text { kesempatan } \\
\text { kepada siswa } \\
\text { untuk mengajukan } \\
\text { pertanyaan }\end{array}$ & $\checkmark$ & & \\
\hline 5 & $\begin{array}{l}\text { Memberikan } \\
\text { kesempatan } \\
\text { kepada siswa } \\
\text { untuk } \\
\text { menyampaikan } \\
\text { pendapat }\end{array}$ & $\sqrt{ }$ & & \\
\hline 6 & $\begin{array}{l}\text { Memberikan } \\
\text { penghargaan } \\
\text { kepada siswa }\end{array}$ & $\sqrt{ }$ & & \\
\hline & PENUTUP & & & \\
\hline 1 & $\begin{array}{l}\text { Menarik } \\
\text { kesimpulan }\end{array}$ & $\sqrt{ }$ & & \\
\hline 2 & Mengevaluasi & & $\checkmark$ & \\
\hline 3 & $\begin{array}{l}\text { Memberikan } \\
\text { tugas }\end{array}$ & $\checkmark$ & & \\
\hline
\end{tabular}




\section{Deskripsi Keadaan Aktifitas Siswa Pada Siklus 1}

Tabel 6. Deskripsi Keadaan Aktifitas Siswa Pada Siklus 1

\begin{tabular}{|c|l|c|c|}
\hline NO & $\begin{array}{l}\text { Aktifitas Siswa } \\
\text { yang Diamati }\end{array}$ & Jumlah & $\begin{array}{c}\text { Persentase } \\
(\%)\end{array}$ \\
\hline 1 & $\begin{array}{l}\text { Menunjukkan } \\
\text { kesiapan } \\
\text { belajar }\end{array}$ & 21 & 70 \\
\hline 2 & $\begin{array}{l}\text { Mendengarkan } \\
\text { penjelasan } \\
\text { guru }\end{array}$ & 22 & 73 \\
\hline 3 & $\begin{array}{l}\text { Mencatat } \\
\text { pelajaran/tugas }\end{array}$ & 27 & 90 \\
\hline 4 & $\begin{array}{l}\text { Mengerjakan } \\
\text { tugas }\end{array}$ & 21 & 70 \\
\hline 5 & $\begin{array}{l}\text { Berdiskusi } \\
\text { dalam } \\
\text { menyelesaikan } \\
\text { tugas }\end{array}$ & 13 & 43 \\
\hline 6 & $\begin{array}{l}\text { Tampil } \\
\text { menyelesaikan } \\
\text { tugas }\end{array}$ & 14 & 47 \\
\hline
\end{tabular}

3. Deskripsi Keadaan Hasil Belajar Siswa Pada Siklus 1

Tabel 3. Deskripsi Keadaan Hasil Belajar Siswa Pada Siklus 1

\begin{tabular}{|c|c|c|c|}
\hline No & $\begin{array}{c}\text { Interval } \\
\text { nilai }\end{array}$ & Jumlah & Persentase $(\%)$ \\
\hline 1 & $<50$ & 4 & 13 \\
\hline 2 & $51-60$ & 6 & 20 \\
\hline 3 & $61-70$ & 6 & 20 \\
\hline 4 & $71-80$ & 6 & 20 \\
\hline 5 & $81-90$ & 3 & 10 \\
\hline 6 & $91-100$ & 5 & 17 \\
\hline \multicolumn{2}{|c|}{ Jumlah } & 30 & 100 \\
\hline \multicolumn{2}{|c|}{ Nilai Rata-rata } & \multicolumn{2}{|r|}{70} \\
\hline \multicolumn{2}{|c|}{ Nilai Terendah } & \multicolumn{2}{|r|}{43} \\
\hline \multicolumn{2}{|c|}{ Nilai Tertinggi } & \multicolumn{2}{|r|}{99} \\
\hline
\end{tabular}

\section{Refleksi pada Siklus 1}

Hasil observasi dari tabel 6.data aktifitas siswa selama siklus pertama sudah menunjukkan peningkatan dalam semua aspek aktifitas yang diamati, yaitu siswa yang menunjukkan kesiapan belajar sebesar $70 \%$, siswa yang mendengarkan penjelasan guru sebesar $73 \%$, siswa yang mencatat pelajaran/tugas sebesar $90 \%$ dan siswa yang mengerjakan tugas mencapai $70 \%$ sedangkan siswa yang berdiskusi dalam menyelesaikan tugas $43 \%$ serta siswa yang tampil menyelesaikan tugas sudah mencapai $47 \%$

Hasil evaluasi Siklus 1, penguasaan siswa terhadap materi pembelajaran yaitu dengan ratarata 70 , dengan penyebaran nilai yang merata serta rentang nilai yang masih terlalu jauh yaitu nilai terendah 43 sedangkan capaian nilai tertinggi yaitu 99

Adapun keberhasilan dan kegagalan yang terjadi pada siklus pertama adalah sebagai berikut

a. Sebagian peserta didik mulai terbiasa dengan kondisi belajar dengan menggunakan papan catur, serta gamet yang sudah disiapkan. Hal ini dapat dilihat dari hasil observasi terjadi peningkatan keterlibatan siswa dalam pembelajaran

b. Sebagian peserta didik masih kurang termotivasi dalam pembelajaran terlihat dari hasil observasi siswa yang tampil menyelesaikan tugas baru sekitar 33\%

c. Masih ada siswa yang belum memahami konsep persilangan menggunakan papan catur terbukti masih ada 4 orang yang nilainya 50 kebawah

d. Hasil belajar peserta didik pada siklus pertama baru mencapai rata-rata 64 . Kemungkinan hal ini disebabkan oleh sulitnya siswa dalam menentukan pemisahan gamet induk yang akan disilangkan

Untuk memperbaiki kelemahan dan meningkatkan keberhasilan yang telah dicapai pada siklus pertama, maka pada siklus kedua dapat dibuat perencanaan sebagai berikut :

1. Memberikan pengarahan pada peserta didik agar dapat lebih fokus dan aktif lagi dalam proses pembelajaran

2. Guru memperbaiki media yang digunakan, yaitu dalam hal :

a. Tampilan busa diciptakan lebih menarik.

Sebelumnya busa yang berwarna dasar hitam diberikan cat berwarna pink. Karena bahannya busa, cat tidak merata sehingga tampilannya kurang menarik 
Pada siklus 2 busa dibuat lebih menarik dengan menutup bahan dasar yang berwarna hitam dengan kain flannel berwarna biru

b. Menyiapkan semua gamet yang dibutuhkan, semua tulisan yang diperlukan ditulis pada busa tipis

c. Semua proses yang terjadi dilakukan diatas busa, mulai dari menentukan parental, pemisahan gamet, menggunakan papan catur serta menentukan genotip dan fenotip hasil persilangan beserta perbandingannya

3. Memberi pengakuan dan penghargaan

\section{Hasil Penelitian Siklus Kedua}

\section{Deskripsi Keadaan Aktifitas Guru Pada} Siklus 2

Tabel 4. Deskripsi Keadaan Aktifitas Guru Pada Siklus 2

\begin{tabular}{|c|c|c|c|c|}
\hline \multirow[b]{2}{*}{ No } & \multirow{2}{*}{$\begin{array}{c}\text { Aktifitas } \\
\text { Mengajar Guru }\end{array}$} & \multicolumn{2}{|c|}{ Kondisi } & \multirow[t]{2}{*}{ Ket } \\
\hline & & Muncul & $\begin{array}{c}\text { Tdk } \\
\text { muncul }\end{array}$ & \\
\hline & PENDAHULUAN & & & \\
\hline 1 & $\begin{array}{l}\text { Mengecek } \\
\text { kehadiran siswa }\end{array}$ & $\checkmark$ & & \\
\hline 2 & Apersepsi & $\checkmark$ & & \\
\hline 3 & Motivasi & $\checkmark$ & & \\
\hline & KEGIATAN INTI & & & \\
\hline 1 & $\begin{array}{l}\text { Menjelaskan } \\
\text { tujuan } \\
\text { pembelajaran }\end{array}$ & $\checkmark$ & & \\
\hline 2 & $\begin{array}{l}\text { Menggunakan } \\
\text { teknik bertanya } \\
\text { yang bervariasi }\end{array}$ & $\checkmark$ & & \\
\hline 3 & $\begin{array}{l}\text { Menjelaskan } \\
\text { materi secara } \\
\text { kontekstual }\end{array}$ & $\bar{\checkmark}$ & & \\
\hline 4 & $\begin{array}{l}\text { Memberikan } \\
\text { kesempatan } \\
\text { kepada siswa } \\
\text { untuk mengajukan } \\
\text { pertanyaan }\end{array}$ & $\checkmark$ & & \\
\hline 5 & $\begin{array}{l}\text { Memberikan } \\
\text { kesempatan } \\
\text { kepada siswa } \\
\text { untuk } \\
\text { menyampaikan } \\
\text { pendapat }\end{array}$ & $\checkmark$ & & \\
\hline 6 & $\begin{array}{l}\text { Memberikan } \\
\text { penghargaan } \\
\text { kepada siswa }\end{array}$ & $\checkmark$ & & \\
\hline & PENUTUP & & & \\
\hline 1 & $\begin{array}{l}\text { Menarik } \\
\text { kesimpulan }\end{array}$ & $\checkmark$ & & \\
\hline 2 & Mengevaluasi & $\checkmark$ & & \\
\hline 3 & Memberikan tugas & $\checkmark$ & & \\
\hline
\end{tabular}

\section{Deskripsi Keadaan Aktifitas Siswa Pada Siklus 2}

Tabel 5. Deskripsi Keadaan Aktifitas Siswa Pada Siklus 2

\begin{tabular}{|c|l|c|c|}
\hline NO & $\begin{array}{c}\text { Aktifitas Siswa } \\
\text { yang Diamati }\end{array}$ & Jumlah & $\begin{array}{c}\text { Persentase } \\
(\%)\end{array}$ \\
\hline 1 & $\begin{array}{l}\text { Menunjukkan } \\
\text { kesiapan belajar }\end{array}$ & 28 & 93 \\
\hline 2 & $\begin{array}{l}\text { Mendengarkan } \\
\text { penjelasan guru }\end{array}$ & 25 & 83 \\
\hline 3 & $\begin{array}{l}\text { Mencatat } \\
\text { pelajaran/tugas }\end{array}$ & 30 & 100 \\
\hline 4 & $\begin{array}{l}\text { Mengerjakan } \\
\text { tugas }\end{array}$ & 25 & 83 \\
\hline 5 & $\begin{array}{l}\text { Berdiskusi dalam } \\
\text { menyelesaikan } \\
\text { tugas }\end{array}$ & 16 & 53 \\
\hline 6 & $\begin{array}{l}\text { Tampil } \\
\text { menyelesaikan } \\
\text { tugas }\end{array}$ & 18 & 60 \\
\hline
\end{tabular}

\section{Deskripsi Keadaan Hasil Belajar Siswa Pada Siklus 2}

Tabel 6. Deskripsi Keadaan Hasil Belajar Siswa Pada Siklus 2

\begin{tabular}{|c|c|c|c|}
\hline No & $\begin{array}{c}\text { Interval } \\
\text { nilai }\end{array}$ & Jumlah & $\begin{array}{c}\text { Persentase } \\
(\%)\end{array}$ \\
\hline 1 & $<50$ & 2 & 7 \\
\hline 2 & $51-60$ & 6 & 20 \\
\hline 3 & $61-70$ & 6 & 20 \\
\hline 4 & $71-80$ & 4 & 13 \\
\hline 5 & $81-90$ & 2 & 7 \\
\hline 6 & $91-100$ & 10 & 33 \\
\hline Jumlah & 30 & 100 \\
\hline Nilai Rata-rata & \multicolumn{3}{|c|}{75} \\
\hline Nilai Terendah & \multicolumn{2}{|c|}{45} \\
\hline Nilai Tertinggi & \\
\hline
\end{tabular}

\section{Refleksi Penelitian Siklus 2}

Hasil observasi proses pembelajaran dan dari tabel 9.data aktifitas siswa selama siklus kedua menunjukkan peningkatan semua aktifitas 
siswa, yaitu siswa menunjukkan kesiapan belajar sebesar 93\%, siswa yang mendengarkan penjelasan guru sebesar $83 \%$, siswa yang mencatat pelajaran/tugas sebesar $100 \%$ dan siswa yang mengerjakan tugas mencapai $83 \%$ sedangkan siswa yang berdiskusi dalam menyelesaikan tugas 53\% serta siswa yang tampil menyelesaikan tugas sudah mencapai $60 \%$.

Hasil catatan lapangan dalam proses pembelajaran selama siklus kedua adalah siswa sudah terbiasa dengan situasi pembelajaran, mereka terlihat lebih serius mengikuti kegiatan dan lebih meningkat keaktifannya, serta terlihat lebih menyenangkan. Mereka berebut ingin menyelesaikan soal persilangan yang diberikan, bahkan ada yang langsung ingin mengerjakan semua tahapan peneyelesaian di depan kelas karena mereka tinggal memilih apa yang dibutuhkan dan menempelkannya pada busa menggunakan paku mading

Hasil evaluasi Siklus Kedua, penguasaan siswa terhadap materi pembelajaran sudah mulai baik, terdapat peningkatan hasil belajar dibanding dari siklus pertama. Pada siklus kedua hasil belajar siswa mencapai rata - rata 75 meningkat 5 poin dari capaian nilai pada siklus pertama dengan rata-rata 70 . Walaupun masih ada 2 orang siswa yang memperoleh nilai pada posisi 50 kebawah namun ada juga 2 orang siswa yang memperoleh nilai sempurna yaitu 100

Penelitian ini dilaksanakan dalam dua siklus yang dilakukan selama 4 minggu. Siklus pertama dilaksanakan pada minggu pertama dan kedua Oktober 2018, sedangkan siklus kedua dilaksanakan minggu ketiga dan keempat Oktober 2018. Tiap minggu terdiri dari 2 kali pertemuan dengan masing-masing pertemuan lamanya 2 x 40 menit dan 3 x 40 menit.

Pengamatan terhadap aktifitas belajar siswa selama kegiatan dari kondisi awal, kondisi pada siklus pertama dan kondisi pada siklus kedua dapat diamati pada grafik berikut:

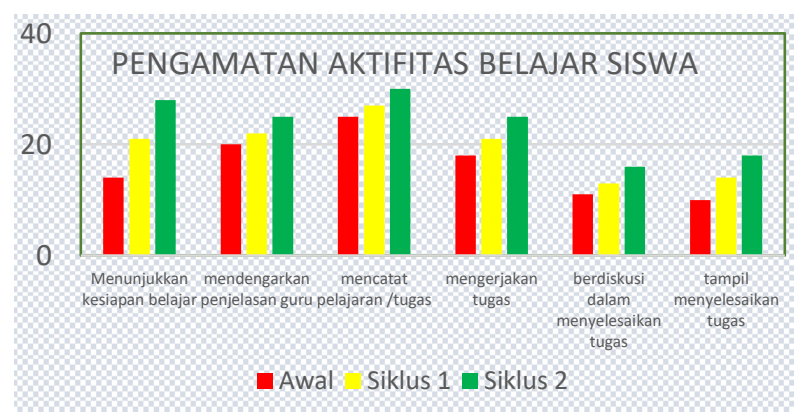

Gambar 2. Grafik Aktifitas Belajar Peserta Didik
Dari grafik terlihat adanya peningkatan semua aspek aktifitas belajar siswa pada setiap tahapan mulai dari kondisi awal, pada siklus 1 dan puncaknya pada siklus 2 .

Kegiatan akhir dari pembelajaran ini adalah mengadakan tes. Tes yang diberikan guru berupa uraian. Tes ini dilaksanakan secara individual dan tidak diperbolehkan kerjasama maupun melihat buku dalam menjawabnya. Hasil-hasil penelitian pada setiap siklus yang sudah dijabarkan sebelumnya, jika dideskripsi kan lagi dalam bentuk perbandingan setiap siklus adalah sebagai berikut:

Tabel 11. Rata - rata Hasil Belajar Peserta didik

\begin{tabular}{|c|l|c|}
\hline No & \multicolumn{1}{|c|}{ Tahapan } & $\begin{array}{c}\text { Rata-rata } \\
\text { Hasil Belajar }\end{array}$ \\
\hline 1 & Kondisi Awal & 64 \\
\hline 2 & Siklus 1 & 70 \\
\hline 3 & Siklus 2 & 75 \\
\hline
\end{tabular}

Data hasil belajar peserta didik dapat dilihat dalam bentuk grafik sebagai berikut :

\section{HASIL BELAJAR PESERTA DIDIK}

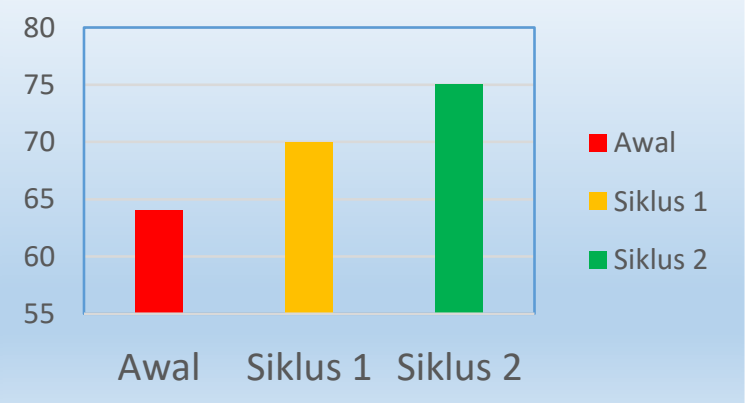

Gambar 3. Grafik Hasil Belajar Peserta Didik

Dari tabel dan grafik diatas dapat terlihat pada kondisi awal nilai rata-rata hasil tes 64 . Nilai rata-rata ini belum memuaskan penulis, hal ini menunjukkan masih rendahnya tingkat penguasaan siswa terhadap materi pelajaran. Penulis merasa harus ada upaya yang segera harus dilkukan untuk memperbaiki kualitas pembelajaran agar diperoleh hasil belajar siswa yang lebih baik lagi.

Hasil tes yang diperoleh pada siklus I masih belum memuaskan, walaupun rata-rata nilai siswa sudah mengalami peningkatan dari kondisi awal yaitu 70 yang sebelumnya dengan rata-rata 64. Rentangan nilai yang diperoleh siswa masih terlalu jauh yaitu nilai terendah 43 sedangkan nilai tertinggi mencapai posisi 99

Hasil tes yang diperoleh pada siklus II sudah cukup memuaskan, dimana sudah terjadi peningkatan hasil belajarnya dengan perolehan 
nilai rata-rata siswa sudah menjadi 75 , walaupun dengan rentangan nilai yang masih jauhdan sangat ekstrim dimana masih ada 2 orang siswa yang nilainya pada posisi 50 kebawah dan ternyata juga ada 2 orang yang mampu memperoleh nilai sempurna yaitu 100

Melalui penggunaan media papan catur pada materi genetika atau pewarisan sifat dengan melibatkan siswa memilih gamet dan melakukan persilangan secara langsung dipapan tulis ini terlihat bahwa siswa dapat mengikuti pembelajaran dengan lebih termotivasi untuk belajar di bandingkan dengan metode pembalajaran dimana siswa lebih cenderung pasif sehingga motivasi belajar peserta didik rendah dan pada akhirnya mengakibatkan rendahnya hasil belajar siswa pada saat dilaksanakan tes.

Penggunaan media papan catur dan disediakannya semua bahan yang dibutuhkan dari proses awal persilangan seperti genotip dari parental, proses pemisahan gametnya, memasukkan gamet tersebut pada papan catur dan melakukan persilangan kemudian sampai pada tahapan menentukan genotip dan fenotip hasil persilangan menimbulkan antusiasme peserta didik makin meningkat dalam mengikuti setiap kegiatan. Ini terbukti dari hasil penelitian, aktifitas siswa pada 6 aspek yang diamati mengalami peningkatan yang cukup meng gembirakan serta hasil belajar peserta didik juga mengalami peningkatan dari kondisi awal sampai berakhirnya dilaksanakan siklus 2 .

Dari uraian di atas dapat disimpulkan bahwa penggunaan media papan catur pada materi genetika atau pewarisan sifat telah dapat meningkatkan hasil belajar siswa kelas IXa pada semester I tahun ajaran 2018/2019 di SMPN 4 Kota Solok.

\section{Kesimpulan}

\section{KESIMPULAN}

Berdasarkan hasil penelitian Tindakan Kelas dengan penggunaan media papan catur selama kedua siklus dapat diambil kesimpulan bahwa: 1) Pada siklus pertama sudah terjadi peningkatan hasil belajar siswa namun masih perlu ditindaklanjuti karena rata-rata hasilnya masih belum mencapai kriteria keberhasilan. 2) Sedangkan pada siklus kedua sudah terjadi peningkatan hasil belajar siswa walaupun hanya sedikit. 3) Dengan penggunaan media papan catur yang dilaksanakan dapat meningkatkan hasil belajar IPA siswa kelas IXa SMPN 4 Kota Solok.

\section{Saran}

Berdasarkan kesimpulan yang telah diperoleh dalam penelitian ini, diajukan beberapa saran untuk dipertimbangkan: 1) Guru dapat menggunakan media papan catur pada materi genetika dengan melibatkan siswa secara aktif sehingga pembelajaran akan lebih bermakna dan meningkatkan penguasaan siswa terhadap pelajaran. 2) Guru diharapkan dapat mencari variasi lain dalam pembelajaran genetika agar diperoleh peningkatan hasil belajar yang lebih signifikan. 3) Guru-guru yang sudah pernah mengikuti penataran berhubungan dengan peningkatan pelaksanaan pembelajaran, agar dapat mempraktekkan dalam proses belajar mengajar agar hasil belajar siswa menjadi lebih baik. 4) Guru agar dapat menggunakan variasi dalam pelaksanaan pembelajaran agar siswa tidak merasa bosan dan supaya siswa termotivasi dalam belajar. Disamping itu pengelolaan kelas dan pemberian penghargaan juga tidak bisa diabaikan, karena semuanya itu dapat menciptakan situasi belajar yang kondusif. 5) Kepada siswa untuk menyadari bahwa pelajaran IPA adalah salah satu mata pelajaran penting yang perlu untuk dikuasai.

\section{DAFTAR PUSTAKA}

Ariany, Y., Ardi, A., \& Rahmi, Y. L. (2018). Analisis Pemahaman Guru IPA seKecamatan Lima Kaum terhadap Pelaksanaan Standar Proses dan Standar Penilaian Kurikulum 2013. JURNAL EKSAKTA PENDIDIKAN (JEP), 2(1), 5663.

Dimyati, Mudjiono (2015). Belajar dan Pembelajaran., Jakarta: Rineka Cipta

Ghozi, S. A. (2017). Peningkatan Pemahaman Konsep Keliling, Luas Persegi Dan Persegi Panjang Melalui Pendekatan Pmri Berbantuan Media Papan Catur Siswa Kelas Iii Sdn Sumbersoko 01 (Doctoral dissertation, UMK).

Indonesia. (2015) Buku Guru Ilmu Pengetahuan Alam/ Kementerian Pendidikan Kebudayaan, Jakarta: Kementerian Pendidikan dan Kebudayaan 
Jihad, Asep (2010). Pendidikan Karakter Teori dan Aplikasi. Jakarta: Kementrian Pendidikan Nasional

Lestari, Y. P., Slameto, S., \& Radia, E. H. (2018). Penerapan Pbl (problem Based Learning) Berbantuan Media Papan Catur untuk Meningkatkan Hasil Belajar Matematika Kelas 4 SD. JURNAL PENDIDIKAN DASAR PERKHASA: Jurnal Penelitian Pendidikan Dasar, 4(1), 53-62.

Muslich, Masnur (2012). Melaksanakan PTK Itu Mudah. Jakarta: PT Bumi Aksara.
Sani, Ridwan Abdullah dan Sudiran (2017). Penelitian Tindakan Kelas Pengembangan Profesi Guru. Tangerang: Tira Smart.

Suyono dan Hariyanto (2011). Belajar dan Pembelajaran. Bandung: PT Remaja Rosdakarya.

Usmeldi (2017). Efektivitas Penerapan Media Pembelajaran Interaktif Dengan Software Autorun Untuk Meningkatkan Kompetensi Fisika Siswa SMK Negeri 1 Padang. Padang: Jurnal Eksakta Pendidikan 